NBER WORKING PAPER SERIES

\title{
DOES MANAGED CARE CHANGE THE MISSION OF NONPROFIT HOSPITALS? EVIDENCE FROM THE MANAGERIAL LABOR MARKET
}

\author{
Richard Arnould \\ Marianne Bertrand \\ Kevin F. Hallock \\ Working Paper 7924 \\ http://www.nber.org/papers/w7924 \\ NATIONAL BUREAU OF ECONOMIC RESEARCH \\ 1050 Massachusetts Avenue \\ Cambridge, MA 02138 \\ September 2000
}

\begin{abstract}
We are very grateful to seminar participants at the NBER Conference on the Industrial Organization of Healthcare and to Sendhil Mullanaithan for many helpful comments. We also thank Srikanth Kadyala for excellent research assistance. This research was supported by a grant from the National Bureau of Economic Research. Most of the research was completed while Bertrand was at Princeton University. The views expressed are those of the authors and not necessarily those of the National Bureau of Economic Research.

(C) 2000 by Richard Arnould, Marianne Bertrand, and Kevin F. Hallock. All rights reserved. Short sections of text, not to exceed two paragraphs, may be quoted without explicit permission provided that full credit, including (C) notice, is given to the source.
\end{abstract}


Does Managed Care Change the Mission of Nonprofit Hospitals?

Evidence From the Managerial Labor Market

Richard Arnould, Marianne Bertrand, and Kevin F. Hallock

NBER Working Paper No. 7924

September 2000

JEL No. J44, L3, I11

\section{$\underline{\text { ABSTRACT }}$}

This paper examines how the managerial labor market in nonprofit hospitals has adjusted to the negative income pressures created by HMO penetration. Using a panel of about 1500 nonprofit hospitals over the period 1992 to 1996, we find that top executive turnover increases following an increase in HMO penetration. Moreover, the increase in turnover is concentrated among the hospitals that have low levels of economic profitability and are more financially leveraged. While the link between top executive pay and for-profit performance measures is on average very weak, HMO penetration substantially tightens that link: as HMO penetration increases, top executives are compensated more for improving the profitability of their hospitals. These results are consistent with the view that HMO penetration increases the importance of for-profit performance objectives among not-for-profit hospitals. Boards appear to fire the managers that are least able to compete in the new competitive environment and reward incumbent managers more for achieving for-profit goals. Consistent with donors' belief that these changes represent a weakening of the nonprofit mission and not simply an attempt by altruistic boards to protect intergenerational equity, we find that public donations fall as HMO market share increases.

Richard Arnould

Department of Economics University of Illinois 1206 South Sixth Street

Champaign, IL 61820

rarnould@uiuc.edu

Kevin F. Hallock

Department of Economics University of Illinois 1206 South Sixth Street

Champaign, IL 61820

hallock@uiuc.edu
Marianne Bertrand

Graduate School of Business

University of Chicago

1101 East 58 th Street

Chicago, IL 60637

and NBER

marianne.bertrand@gsb.uchicago.edu 
Substantial changes have occurred over the last ten to twenty years in the hospital sector. One of the most important of these changes has without doubt been the growth in Health Maintenance Organizations (HMOs) and Preferred Provider Organizations (PPOs). While in the past hospitals competed mostly on the quality of care they provided, the spread of managed care has introduced competition on cost as well. In this paper, we ask whether the negative income effect associated with the expansion of medical plans has altered the objectives of nonprofit hospitals. Did nonprofit boards change their organizational objectives and become more profit-oriented in the face of the growing managed care market? This is an especially important question as it touches on the efficiency and viability of maintaining policy incentives to organize along the nonprofit form in an industrial sector that becomes more and more competitive.

Such a change in objectives could be expected under at least two theoretical models of nonprofit organizations. Consider first a purely altruistic model where nonprofit hospital boards are motivated by a desire to improve social well-being rather than to maximize profits (Drucker, 1990). For example, altruistic boards truly value achieving high levels of service quality or providing charitable care. Another natural goal for these boards may be to provide for the needs of many future generations of patients. Negative income pressures (such as those induced by the spread of managed care) endanger intergenerational equity as they seriously heighten the risk of a financial failure. In response, nonprofit boards may decide to make economic survival a primary objective, at least as long as the likelihood of distress stays large. In the alternative model, nonprofit boards are not fundamentally altruistic but act as if they were. They do so because their incentive to maximize profits is softened by their inability to distribute such profits to themselves (Hansmann, 1996). They can only benefit from cost-cutting, qualityreducing activities by increasing their perquisites, not by increasing their cash transfers. Nonprofit boards can therefore commit to higher quality services than for-profit boards as long as receiving compensation in the form of perquisites is worse than receiving cash (Glaeser and Shleifer, 1998). Because a negative 
shock to income will increase the marginal value of such perquisites, it will also strengthen the for-profit incentives. Hence, both models predict that the nonprofit hospitals that are subject to negative income pressures will start focusing more on economic profits.

Directly assessing whether not-for-profit hospitals have indeed become more driven by, say, accounting rates of return is not an easy task. For example, no simple inference could be made from directly looking at trends in hospital outcome measures. Frank and Salkever (2000) document that profitability margins for not-for-profit hospitals fell substantially in the latter half of the 1980s and have remained low since then. While this could be construed as evidence that not-for-profit hospitals have not taken up for-profit goals, this could also result mechanically from the greater income pressures introduced by the managed care industry!

Our approach in this paper is to indirectly evaluate any changes in organizational goals by studying changes in the managerial labor market in nonprofit hospitals. We believe that two different aspects of the managerial labor market are relevant here. First, we ask whether the allocation of managerial talent at the head of nonprofit hospitals was affected by the spread of managed care. We study whether there was an increase in top executive turnover with the increase in HMO penetration, and if yes, which managers were more likely to be replaced. Evidence that income pressures lead to more displacement among the poor economic performers would be suggestive of a shift toward a higher valuation of for-profit goals by nonprofit boards. Alternatively, finding that it is instead the managers that are the weakest in providing a high level of quality of care that are more likely to be replaced would be suggestive of a reinforcement of the pure nonprofit mission.

Second, we exploit some implications of standard agency theory to learn more about the objectives that nonprofit boards want to maximize. In a simple principal-agent model, boards of directors

\footnotetext{
${ }^{1}$ Several authors have recently noted a weakening in the provision of charity care as market pressures increase. Currie and Fahr (2000) provide some evidence that managed care reduced the medicaid caseload in nonprofit hospitals. Similarly, Duggan (2000) shows that nonprofit hospitals that are surrounded by more for-profit hospitals devote a smaller share of their care to the indigent. None of these papers however directly document a rise in the for-profit objectives.
} 
tie their managers' pay to the organizational outcomes that they value and that are influenced by the managers' effort. The work of Murphy (1985), Jensen and Murphy (1990) and scores of others has empirically applied this idea to the for-profit sector. These authors have shown that CEO compensation in publicly traded corporations is linked to measures of economic performance such as accounting rate of return or shareholder wealth. Under the assumption that nonprofit boards also need to provide incentives to their officers, one can infer some of the organizational objectives by investigating which hospital outcomes are correlated with managerial pay. We then ask whether HMO penetration has qualitatively and/or quantitatively altered the link between managerial pay and various hospital outcome measures.

While this paper focuses on a very specific sector within the nonprofit world, the question of how financial pressures affect nonprofits' objectives is of much wider relevance. It has been anecdotally noted (Weisbrod, 1998) that many nonprofit sectors have become more and more commercialized. Higher education, museums, and public television broadcasting are often cited as examples. Going beyond the anecdotal evidence and understanding the role that financial pressures, such as those induced by for-profit competition, have played in this apparent change of mission is crucial for assessing the future of the nonprofit form. Our focus on the hospital industry is in large part motivated by the intrinsic importance of this industry as the largest nonprofit sector in the economy. It is also motivated by two more practical issues. First, measures of not-for-profit performance can more easily be computed in this sector. For example, the number of nurses per patient day or dollars spent on program services per patient day capture, admittedly imperfectly, some aspects of the quality of care It is more difficult to think of reasonable nonprofit objective proxies for many of the other nonprofit sectors. Moreover, even if one can find such good proxies, data limitation issues are often binding. Second, the growing involvement of managed care in the hospital industry offers a rather unique and clean experiment to study the effect of a negative income shock on nonprofits' objective functions.

\footnotetext{
${ }^{2}$ Optimally, we would have liked to use better proxies of quality of care such as risk-adjusted mortality rates. Unfortunately, such mortality rates exist for only a subsample of the hospitals in our sample and, most importantly, are not available to us in a panel format.
} 
Our results suggest that the negative income pressures on the hospital industry have affected the objectives that nonprofit boards are seeking to achieve. First, we find that HMO penetration led to an increase in managerial turnover. In addition, it is among the hospitals that started with the weakest profitability and the lowest endowment (or highest financial leverage) that the increase in turnover was the strongest. Second we find that as managed care spreads managerial pay becomes more sensitive to accounting rates of return and to profit margins. However, there is no sign of a direct reduction in the reward for high rate of program services per patient ${ }^{3}$ Instead, there is some suggestive evidence that nonprofit boards are now paying closer attention to achieving these nonprofit goals in an efficient way. Finally, our paper offers some suggestive evidence that donors regard these changes as a weakening of the non-profit mission. Consistent with donors' belief that hospitals are not purely altruistic and are not simply aiming to protect intergenerational equity, we find that public donations fall following an increase in HMO market share.

The findings in this paper complement previous work on hospital conversions. Several authors (Cutler and Horwitz, 2000, Weisbrod, 1998, Goddeeris and Weisbrod, 1998, Abelson, 1998) have documented a rather rapid shift to for-profit status in the hospital market. Cutler and Horwitz (2000) note that these conversions are driven, at least in part, by the heightened financial pressures in the new health care market. Our results suggest that even among the hospitals that maintained their nonprofit status, the market pressures also led to a change in organizational goals. It is also possible that this change in goals created enough tensions inside of the nonprofit organization to ultimately lead to a conversion. Our findings are also consistent with anecdotal and survey evidence such as in Frank and Salkever (2000). These authors report results of focus group discussions with (mostly nonprofit) hospital managers in the Boston and Chicago areas. Frank and Salkever (2000) summarize the contents of these discussion as “...implying a large weight on current and future profits in the face of perceived financial and competitive pressures."

\footnotetext{
${ }^{3}$ Obviously, incentives to provide high quality care or help the indigent must have been indirectly weakened
} 
The rest of the paper is organized as follows. Section 2 describes data sources, data construction and empirical approach. Our sample consists of a panel of about 1500 not-for-profit hospitals over the period from 1992 to 1996 . It was constructed using data from the Annual Survey of the American Hospital Association (AHA), and the Internal Revenue Service. We also describe the HMO penetration measure in Section 2. Section 3 describes the basic pay-for-performance relationship in our data set, using both for-profit and not-for-profit performance measures. Section 4 investigates the impact of managed care growth on top managers' turnover and on the allocation of managerial talent in nonprofit hospitals. Section 5 studies the impact of the HMO penetration on the nature and strength of the various pay-forperformance links. Section 6 shows how public donations reacted to the new competitive environment. Section 7 offers concluding comments.

\section{Data Description and Empirical Approach}

We use three different data sources in this paper. The first data source includes detailed compensation information for managers of nonprofit hospitals as well as some accounting and financial variables for the hospitals. It is collected from the Internal Revenue Service (IRS). The second data source is the American Hospital Association (AHA) Annual Survey. This source includes information on a large set of hospital characteristics as well as the name of hospital top managers, which we will use to compute managerial turnover. The last data source contains information on HMO penetration rates.

\subsection{IRS Data}

The IRS data come from the tax returns of " $501 \mathrm{c}(3)$ " tax-exempt organizations and cover the period from 1992 to 1996. The base sample includes more than 25,000 organizations filing Form 990 returns 
each year from 1992 to 1996 . We then needed a way to separate hospitals from all other 501c(3) nonprofits. The National Taxonomy of Exempt Entities (NTEE) has been developed to help classify charitable nonprofits into specific groups. The NTEE codes are similar to SIC industry codes for firms. In the end, there are a total of 645 unique subgroups in the NTEE ${ }^{4}$ We selected the sub-grouping for hospitals and related primary medical care facilities.

For each top executive we collected three measures of compensation and a host of accounting and financial information on the hospital he or she manages. To compute the compensation measure, we extracted information on 1) base compensation including "salary, fees, bonuses, and severance payments paid" (Internal Revenue Service 1996), 2) contributions to employee benefit plans and deferred compensation including "medical dental and life insurance" (Internal Revenue Service 1996), and 3) expense account and other allowances including "expense allowances or reimbursements that the recipient must report as income on their separate income tax returns. ${ }^{\text {G }}$ Examples include amounts for which the recipient did not account to the organization or allowances that "were more than the payee spent on serving the organization." Organizations are required to include such payments as "the value of the personal use of housing, automobiles, or other assets owned or leased by the organization." (Internal Revenue Service 1996). For the purpose of our paper, we combine these 3 variables into a single measure of "total compensation." As seen in Table 1, the average top officer of the hospitals in our sample earned $\$ 241,000$ (1996 dollars). Note that one major weakness of the IRS data compared to standard databases on for-profit managers' compensation is the absence of demographic controls. We observe neither the age nor the tenure of the top executives in our sample.

Table 1 also reports means and standard errors for a set of the accounting and financial variables that we directly extracted or constructed from the IRS. For example, the average assets, revenue, and expenses for the nonprofit hospitals in our sample over this period are \$123 million, \$119 million, and

\footnotetext{
${ }^{4}$ See Stevenson, Pollak, and Lampkin (1997) Appendix B, Hodgkinson (1990), Hodgkinson and Toppe (1991), Gronbjerg (1994) and Turner, Nygren, and Bowen (1992) for more details on the NTEE.
} 
$\$ 113$ million respectively. We will use the measures of return on assets and profit margins summarized in Table 1 as proxies for for-profit objectives.

\subsection{AHA Annual Survey Data on Hospitals}

In order to complement the IRS data, we collected additional information on hospitals and hospital managers from the American Hospital Association (AHA) for the years 1992 to 1996. Each year, the AHA completes an "annual survey of hospitals" and then distributes (for a fee) the "Annual Survey of Hospitals Data Base." These data have been distributed since 1946 and include a wide variety of interesting variables including hospital location, hospital ownership form, types of facilities and services provided, number of beds, inpatient days and size of staff. We restrict our sample to general medical and surgical hospitals only (service code 10 in the AHA data).

Among some specific data fields that we use from the AHA are the zipcode of the hospital (so we can merge to the HMO penetration rates below), and the name of the hospital (so we can merge to the IRS data). We also concentrate on a variable that contains the name of the top administrator of the hospital. We use this variable to construct our measure of top executive turnover. Since the names of the hospital managers are included as text, creating a variable for managerial turnover required us to check for name changes by hand. Table 1 shows that the average turnover rate for managers of hospitals in our sample is 0.129. We also collected information on the number of Medicaid patients, the number of full time doctors and the number of full time registered nurses that we normalized by the number of inpatient days. As usual, the inpatient days measure is adjusted to account for the number of "one day" admissions. Later in the analysis, we will use these measures as proxies for the provision of charitable care and for the quality of hospital care.

\footnotetext{
${ }^{5}$ Because the IRS data does not report salary and bonus separately, we are not able to study the differential impact of HMO penetration on these various components of compensation.
} 
Merging the AHA data to the IRS data presents some difficulties. Both the AHA and the IRS data sets include unique identification codes but unfortunately these codes are not compatible. This forced us to match organizations by name and zipcode. In the cases where the two sources specified exactly the same hospital name, this process was easy. However, in many cases, the names were either misspelled or spelled slightly differently so that a substantial part of the matching had to be done by hand.

\subsection{HMO Penetration Rates}

Our measure of managed care penetration is the county-level HMO market share. This market share is defined as the ratio of the number of HMO enrollees to the number of beneficiaries in the county. The data were created and provided to us by Lawrence Baker. The basic source for the data is the National Directory of HMOs which is published each year by the Group Health Association of America. The directory surveys all HMOs in the U.S. and questions them about the area they service and their total enrollment. Using these data is difficult because HMOs can span several different regions and because "HMO enrollment may be concentrated near HMO headquarters or ... HMOs may locate their headquarters in areas where their enrollment is concentrated" (Baker and Brown, 1997). However Baker and Brown find that their HMO measures are relatively insensitive to alternative ways of dealing with these issues. Market share estimates were then created as the fraction of the total population participating in HMOs. (Baker and Brown, 1997). Baker (1995) provides many more details of the construction of the data. The average level of HMO penetration in our sample is $15.4 \%$ (Table 1). It is also clear from Figure 1 that the HMO penetration rate has been increasing steadily throughout our sample period.

Research on the effects of managed care, either relying on the data we use here or on alternative data sources (such as hospital discharge data), has been very active. First and foremost, there has been a widespread interest in assessing the impact of HMO penetration on the quality of health care ${ }^{6}$ A large

\footnotetext{
${ }^{6}$ See among others Baker and Shankurkumar (1997) or Baker and Brown (1997).
} 
number of studies have examined the effect of managed care on the process of health care as well as on patients' health outcomes (Feldmann and Sharfstein, 2000). However, no consensus has emerged to this date as to whether managed care plans provide lower quality services than more traditional fee-for-service plans. Fewer papers have examined the effect of HMO penetration on hospital organizational structure and hospital objectives. As we mentioned earlier, Frank and Salkever (2000) provide survey evidence that the spread of managed care may have affected the mission of not-for-profit hospitals. Cutler and Horwitz (2000) report case study evidence that the rising trend in conversion to for-profit status is in part due to the downward price pressures and more stringent financial constraints in the new hospital market. As far as we are aware, our paper is the first attempt to assess the impact of HMO penetration on organizational objectives in a large and representative sample of not-for-profit hospitals.

\subsection{Empirical Approach}

As we mentioned earlier, we perform two major empirical tests in this paper. The first test consists of asking whether the increase in HMO penetration was accompanied by a rise in top executive turnover and, most importantly, which top executives were more likely to be replaced in the face of the growing financial pressures. The second test describes whether and how the pay for performance link was affected by the rise in managed care. All of the specifications below include year effects to control for aggregate shocks either to the turnover rate (first test) or to the compensation level (second test) over the 5-year period under study.

An important estimation issue for us is the possibility of omitted variable biases due to unobserved variables that are correlated with both the managerial labor market variables and HMO penetration. For example, Baker and Corts (1996) have noted that HMOs are more likely to first spread in areas that are dominated by large firms and white collar workers. Because their residents are likely richer, such areas might also attract more modern, better equipped hospitals as well as higher profile 
administrators. Hence managers across different geographic areas might naturally display different compensation levels and turnover patterns that could very well be misconstrued as being a result of HMO penetration.

We directly address this issue in our empirical specifications. Our first empirical model allows for state fixed effects and control for a vector of hospital characteristics including hospital size (logarithm of total assets and logarithm of number of beds), fraction of Medicare patients and type of services provided (for $\mathrm{Z}_{\mathrm{Z}} \mathrm{xample}$, is there an emergency care unit in the hospital). Yet, because there are important sources of heterogeneity left within states and because the hospital characteristics we observe only imperfectly control for such geographic differences, this first specification does not fully solve the omitted variable bias problem. Our second and preferred empirical model, and the one we will most consistently follow in the analysis below, consists of looking within hospitals by allowing for hospital fixed effects. Hence, our empirical specification will identify the causal effect of HMOs as long as the demographic and economic differences that influence HMO penetration are sufficiently stable within regions over the rather short time interval that we study

\section{Basic Pay-for-Performance Relationships among Not-For-Profit Hospital Managers}

Before formally studying the role that managed care has played in reshaping not-for-profit hospitals' managerial market and mission (sections 4 and 5), we describe the basic pay-for-performance relationship in our data set. We begin by briefly reviewing the related literature.

\footnotetext{
${ }^{7}$ Note that we will also control for a vector of time-varying hospital characteristics.

${ }^{8}$ In his study of the impact of HMOs and fee-for-service health care expenditures, Baker (1995) compares estimation results with county fixed effects to IV estimation results where HMO penetration is instrumented with the share of white-collar workers or the share of large firms in the county. The results of both statistical models are
} 


\subsection{Review of Related Literature}

Although there have been hundreds of papers written on the pay and performance of CEOs of forprofit firms, there is very little equivalent empirical work for the nonprofit sector. Hallock (2000a) studies a panel of over 30,000 nonprofit organizations constructed from IRS data. He finds that the size (assets) of the organization is strongly linked to managerial pay, even after controlling for individual organization fixed effects 2 In fact, no other performance measure, either for-profit or not-for-profit, appears to significantly affect pay. This, Hallock (2000a) concedes, could be due to the wide variety of sectors spanned by his data set. It might be difficult to define a not-for-profit performance measure that is relevant across such a large and diverse array of organizations.

Pink and Leatt (1991) study the compensation of managers in 213 nonprofit hospitals in Ontario. They find a weak relationship between hospital surplus and pay but a much stronger link between measures of size such as the number of beds and managerial pay. However, their analysis has important limitations. First, they can only measure the sum of pay for the top five managers in the hospitals, not individual compensation. Second, their entire analysis is performed in levels.

Roomkin and Weisbrod (1999) analyze data from 6,500 general and specialty hospitals in the U.S. using data from a 1992 survey of Hay Management consultants. Among their findings is that pay is higher in the for-profit sector and that the composition of pay (base pay versus bonus) differs by organizational form. They find that bonuses are larger in size in the for-profit sector. They therefore conclude that for-profit hospitals provide more incentives to managers than nonprofit hospitals.

The most recent work is by Brickley and Van Horn (2000). They, like we, use a merged data set from the IRS and the AHA. They find that the relationship between CEO pay and economic performance measures is "as strong in nonprofit hospitals as in for-profit hospitals and other for-profit corporations."

qualitatively similar but magnitudes were larger in the IV model. However, it is clear that the instruments used by Baker would not be valid instruments for our study.

${ }^{9}$ Oster (1998) finds a similar result using data from five separate industries. 
They find little evidence that hospitals in the nonprofit sector motivate their managers based on "altruistic" performance measures.

\subsection{Are For-Profit Objectives Important?}

We begin our empirical analysis by focusing on a set of measures of performance that relate to the measures used in the literature on managerial pay in public corporations (e.g. Jensen and Murphy, 1990). We refer to these measures as "for-profit" objectives and ask whether they are correlated with managerial pay. We consider organizational outcomes such as "return on assets" which is defined as (total revenue - total expenses)/(total assets), "profit margin" which is defined as (total revenue - total expenses)/(total revenue), profit margin from program services which is defined as (program service revenue - program service expense)/(program service revenue), and net assets which represent the sum of the organization endowment and retained earnings.

Table 2 displays our results. All regressions are estimated using Ordinary Least Squares. The dependent variable in all columns is the logarithm of total compensation (as defined above). In column 1, the included regressors are return on assets, a vector of hospital characteristics $\frac{10}{\text {, }}$ state fixed effects, time fixed effects, and a constant. The effect of return on assets is negative and insignificant, which is at odds with the positive and significant relationship commonly found in the literature on CEO pay (e.g. Murphy, 1985). Column 2 of Table 2 presents our preferred specification. Instead of controlling for state fixed effects, we now control for organization fixed effects but continue to control for time varying hospital characteristics. This lets us examine the relationship between changes in return and changes in pay within a specific hospital. Again, the result is negative and insignificant. When we use profit margin as the forprofit objective and look between hospitals (column 3), we find a statistically significant negative

\footnotetext{
${ }^{10}$ Hospital characteristics are: Medicare patient days/adjusted patient days, $\ln$ (total assets), $\ln$ (total number of beds), $\ln ($ revenue), and a vector of indicator variables for whether the hospital has facilities for neonatal intensive care,
} 
relationship between pay and performance. A $1 \%$ increase in the hospital profit margin is associated with about a half percent decline in total compensation for the top manager. That finding is however not robust to the addition of organization fixed effects (column 4). The relationship between compensation and program service profit margin is negative but not statistically significant, whether we use state fixed effects or hospital fixed effects (column 5 and 6).

In columns 7 through 10, we use $\ln$ (net assets) as the performance measure. Again, net assets represent the sum of the organization endowment and of retained earnings. It represents the part of total assets that is not financed though liabilities. We experimented with using current and lagged measures of $\ln$ (net assets) and show results using the lagged performance variable as they appeared to fit the data better. While it does seem that hospitals with lower net assets have higher managerial compensation levels (column 7), the results are different when we look within hospitals (column 8). We find that top executives are rewarded with higher compensation when they increase the size of their net assets. A 1 percent increase in net assets lead to a 0.08 percent increase in compensation. Hence, column 8 provides some evidence that for-profit objectives do matter for executive compensation in not-for-profit hospitals.

We refine this view in columns 9 and 10. We split our original sample in two subgroups based on the base-year financial leverage (liabilities to total assets ratio) of the hospitals in our sample. Because the median base-year leverage is about .5, we break the sample in two groups around that cutoff. We then replicate the specification in column 8 on these two sub-samples. The results are striking. We find that it is only among the hospitals that are the most financially constrained that the link between pay and net asset growth exists (column 10). One interpretation of this effect is that, more than a reward for achieving high economic performance, the link between pay growth and net asset growth could represent boards' desire to maintain sources of funds for future development and future provision of program services. Such concerns for maintaining internal funds must be especially salient in not-for-profit organizations as they have no access to equity finance.

angioplasty, open heart surgery, whether the hospital has a trauma center and whether the hospital has an emergency 
It is important to note as a way to summarize Table 2 that the idea of an overall strong link between pay and economic performance among not-for-profit hospitals does not receive strong support in our data. In fact, when we focus on the hospitals that have not exhausted their debt capacity (column 9), we find no evidence of a pay for economic performance link. This obviously does not exclude the possibility that such a link might appear, even among the low debt capacity hospitals, when we focus on specific episodes of high financial pressures. We will verify that prediction in section 5.

It is also important to note in passing that things look rather different when we consider managerial turnover as an alternative measure of managerial welfare. ${ }^{11}$ We explore the simple relationship between nonprofit hospital managerial turnover and our set of for-profit performance variables in Table 3. The organization of this table follows the structure of the first 8 columns of Table 2 but the dependent variable is now a dummy variable set equal to 1 if there is a new top manager this year and zero otherwise. 12 Also, each of the for-profit performance variables have now been lagged by one year. We find that managers are less likely to turn over when financial performance improves. In the specifications including organization fixed effects (even columns), the impact on turnover is significant for all performance measures except $\ln$ (net assets). ${ }^{13}$ Hence, while nonprofit hospital boards do not in general have in place sophisticated compensation packages that tie pay to economic performance, they appear ready to physically replace those administrators that are underperforming financially.

\footnotetext{
department.

${ }^{11}$ Although very few managers are actually publicly fired (Vancil, 1987), there is a careful and established literature on the relationship between firm performance and CEO turnover in the for-profit sector. Examples from this literature include Warner, Watts, and Wruck (1988) who find that as firm performance decreases the probability of a change in top management increases, Weisbach (1988) who finds that there is a stronger connection between poor firm performance and CEO resignation in firms dominated by outside directors than for firms dominated by insiders, and Murphy and Zimmerman (1993).

${ }^{12}$ We also performed this analysis using logits and probits and found very similar results.
} 


\subsection{Are Not-For-Profit Objectives Important?}

It seems natural to now turn to not-for-profit measures of performance and repeat the same analysis. As described above, we have created several measures of not-for-profit performances from our AHA and IRS data. Ln(program service expenses/adjusted patient days), $\ln$ (number of full time registered nurses on payroll/adjusted patient days) and $\ln$ (number of full time doctors and dentists on payroll/adjusted patient days) are our proposed measures of quality of care. We use the share of Medicaid patients as a measure of charity care ${ }^{14}$ We investigate the relationship between these performance measures and managerial pay in Table 4. For the sake of space, we only report results including hospital fixed effects. We find that more program services expenditures per patient day (column 1), more nurses per patient day (column 2) and more doctors per patient day (column 3) all imply higher level of pay. This effect is however not statistically significant for nurses ${ }^{[15}$ For example, a 10 percent increase in program services expenses per patient increases managerial pay by 2 percent.

While there appears to be a reward for quality of care, we find a negative relationship between pay and fraction of patients on Medicaid (column 4), which could indicate that managers are not encouraged by boards to provide charity care to their community. However, when we consider the four non-profit performance measures at the same time (column 5), only the positive coefficients on $\ln$ (program service expenses/adjusted patient days) and $\ln ($ number of full time doctors/adjusted patient days) appear robust. The negative impact of the Medicaid market share becomes both economically and statistically

\footnotetext{
${ }^{13}$ Eldenberg, Hermalin, Weisbach, and Wosinska (2000) report similar findings for California hospitals. They find a strong negative relationship between financial performance and CEO turnover in both for-profit and nonprofit hospitals (while the relationship is weaker for government and religious hospitals).

${ }^{14}$ In practice, we would also like to use the fraction of uninsured patients as another proxy for the provision of charity care but that information in not available in the AHA data.

${ }^{15}$ Note that the coefficient on number of nurses per adjusted patient day becomes statistically significant in a regression that includes state fixed effects and hospital characteristics but excludes hospital fixed effects.
} 
insignificant. 16 The same pattern holds in column 6 where we further control for the rate of return on assets. Moreover, the financial performance measure remains unrelated to managerial pay.

We complete our analysis of the basic pay-for-performance relationship in nonprofit hospitals by studying in further details the link between program expenses and managerial pay (columns 7 to 9 in Table 4). First, we note in column 7 that it is total expenses (that is, not just expenses on program services, nurses or doctors which we believe to be associated with helping patients) per patient day rather than program expenses per patient day that are positively related to managerial pay. In fact, column 8 and 9 indicate that it is total expenses more than total expenses per patient day that matter in setting managerial pay. It thus appears that hospital managers are rewarded for spending more in general and not just spending more on medical services per patient. This suggests some potentially important inefficiencies in the fulfillment of the nonprofit mission. Note also that this last finding in column 9 does not simply capture an organization size effect as we directly control for $\ln$ (total assets) in the regression. 18 We now turn to the core of our analysis and study how HMO penetration affects both the allocation of managerial talent and the pay-for-performance relationships we just described.

\section{HMO Penetration and the Allocation of Managerial Talent}

Under the hypothesis that HMO penetration modified the objective function of not-for-profit hospitals, one would expect the pool of managers in these hospitals to adjust to the new environment. More specifically, assume that HMO penetration has indeed increased the importance of the for-profit

\footnotetext{
${ }^{16}$ Note that the coefficients on program services expenses per adjusted patient day and number of doctors per adjusted patient day remain unchanged when we directly control for the logarithm of the number of adjusted patient days in the regression (not reported in the tables). Moreover, the coefficient on $\ln$ (patient days) itself is in general positive.

${ }^{17}$ Obviously, some of these expenses, while not for patient services, could still be for valued amenities, such as the construction of more parking spaces, or the opening of new restaurants or new shops.

${ }^{18}$ In regressions not reported here, we have also investigated the relationship between managerial turnover and nonprofit performance measures. We found that turnover increases with expenses and decreases (though not significantly) with the market share of Medicaid patients.
} 
goal in the not-for-profit sector. This should have reduced the demand for hospital managers who are less prepared to achieve the objectives of profitability, even if these managers were good in their role as providers of charity and quality care. In other words, HMO penetration should lead to a re-allocation of managerial talent in the hospital industry. In this section, we investigate whether such changes in the market for not-for-profit hospital managers indeed occurred.

Table 5 investigates whether HMO penetration led to an increase in turnover for the top executives in our data. Again, for the sake of preserving space, we only report the specifications including organization fixed effects which control for any fixed differences in turnover among the hospitals in our sample. We also allow for year fixed effects in order to capture any aggregate shock to turnover. All regressions are estimated using a linear probability model. In column 1 of Table 5, we find that the increase in HMO penetration led to an increase in turnover. We find that a 1 percentage point increase in HMO penetration leads to a statistically significant 0.7 percentage point increase in the probability of top executive turnover.

A higher level of turnover in response to higher levels of HMO penetration is only a necessary condition to support the hypothesis of re-allocation of managerial talent described above. As a next step, we need to establish whether the increased top executive turnover was concentrated among the hospitals with the worst for-profit performance results. ${ }^{19}$ In other words, are the CEOs that are recording lower levels of profitability more likely to be replaced when financial pressures get more intense? The remainder of Table 5 helps us answer this question.

In columns 2 to 5 of Table 5, we ask whether the increase in turnover was higher among hospitals that had lower base-year levels of return on assets, lower base-year profitability margins on their total operations and lower base-year profitability margins on their program service operations. The base year

\footnotetext{
${ }^{19}$ One would also want to know more about the characteristics of the newly hired managers. For example, one would like to know whether the newly hired executives have received more business training. Unfortunately, that information is not available in our data. Included in Cutler and Seinfeld (2000), however, is a careful analysis of the backgrounds of hospital managers. They use data from the 1982 and 1991 American College of Health Care Executives. One of their findings that is especially relevant for our work is that "financial acumen matters." (p. 4).
} 
is defined for each hospital as the first year a hospital appears in our dataset. We find that, while there is no significantly higher HMO-induced turnover among the hospitals that have low rates of return on assets, a clear pattern emerges with respect to the other financial performance measures. It is among the hospitals that have lower profitability margins, both overall and on their program service operations (columns 3 and 4 respectively), that the increase in turnover was the highest. Hence, these results provide support for the view that it is among the CEOs that have performed the worst along the for-profit dimension that the largest increase in turnover is concentrated.

Profitability margins obviously are correlated with other hospital characteristics. One might therefore be concerned that our results in columns 3 and 4 do not, in fact, reflect a differential increase in turnover among the poorly financially performing hospitals. An important example is that hospitals of different sizes may react differently to the new financial pressures. This is an issue for the validity of our previous findings if size and profitability margins are correlated. We investigate this point in column 5. In this column, we allow for interactions of HMO penetration with both base-year overall profitability and base-year $\ln$ (total assets). We find that allowing for a size effect does not alter the profitability effect at all.

We saw in Table 3 that among the hospitals with higher levels of liabilities (relative to the size of their total assets) top executives are incentivized to increase net funds, or grow the size of the hospital's net assets. We ask in columns 6 and 7 whether such preexisting financial pressures also result in a higher responsiveness of turnover to HMO penetration. In column 6, we interact HMO penetration with the base-year ratio of debt liabilities to total assets. As expected, the coefficient on the interaction term is positive, even though only statistically significant at the 11 percent level. Higher leverage and lower net funds lead to more managerial reallocation as a response to the spread of managed care. Column 7 shows that this leverage effect is not entirely driven by a positive correlation between hospital size and hospital debt to assets ratio. While the interaction term between leverage and HMO penetration loses in statistical significance, it is economically affected. 
We next examine whether there is any evidence of a differential increase in turnover based on the ability of the existing managers to fulfill their not-for-profit objectives. We first use base-year measures of the three quality of care proxies introduced before: program services expenditures per adjusted patient day, number of full time registered nurses per adjusted patient day and number of full time physicians and dentists per adjusted patient day (columns 8, 9, and 10 respectively). We find no evidence that low level of expenses or medical staff per patient day leads to a statistically different turnover response. We also consider a base-year measure of the fraction of Medicaid patients (column 11). We find that turnover increases more with HMO penetration among the hospitals that have a larger fraction of Medicaid patients. This last result suggests that the managers that provide higher levels of charity care are more likely to be replaced when managed care expands.

The last column of Table 5, column 12, summarizes our previous findings by putting interactions for overall profitability margin, financial leverage and Medicaid share all in the same regression. We find the same patterns as the ones observed when these variables are introduced individually, even though both the leverage and the Medicaid share interactions are no longer statistically significant at reasonable levels. In summary, the evidence in Table 5 is consistent with the original prediction that more financial pressures on nonprofit hospitals result in the removal of the top managers that are the least able to fulfill for-profit goals and, to a lesser extent, are providing the highest level of charity care. Also, while we do not want to push this result too far, it is interesting that the top executives that have achieved a good quality of care (i.e. the top managers in hospitals with high base-year level of program service expenditure or full time staff per adjusted patient days) do not appear more likely to be replaced. This might indicate that, while for-profit objectives appear to have become more central in boards' optimization problems, quality objectives may not have become a "bad." We will come back to related evidence in the next section. 
What do all of these changes imply for top executives' pay? Intuitively, one would expect the spread of managed care to lead to an increase in nonprofit hospital managers' pay. 20 Nonprofit hospital boards must now have to tap into the pool of for-profit hospitals' managers when looking to replace previous managers with low business management skills. And for-profit hospitals typically pay higher salaries. Roomkin and Weisbrod (1999), for example, study the 1992 Hospital Compensation Survey conducted by Hay management consultants and find that the pay of a top executive in for-profit hospitals is higher than the pay of an executive holding a similar job in a nonprofit hospital of similar size. Moreover, even among the hospitals that are not replacing their top manager, the higher risk of a turnover that is apparently associated with wider HMO presence could in itself generate higher compensating salaries. 21

Unfortunately, our ability to carefully investigate this question is limited by the absence of good demographic controls for managers in our data. Because we know neither top managers' age nor their experience (either total experience or length of tenure on their current job), we cannot easily account for these important determinants of pay in our analysis. Omitting controls for age and experience is likely to bias our results towards finding a negative effect of turnover on pay if younger and less experienced individuals replace older executives.

Keeping this caveat in mind, we study the effect of HMO penetration on mean pay in Table 6. In column 1, we explore the correlation between HMO penetration and mean pay, simply controlling for state and year fixed effects. The effect is large and positive. A 1 percentage point increase in HMO penetration leads to an increase in mean pay for the top executives of $1.7 \%$. Column 2 clearly establishes that a large part of this effect does not reflect a direct effect of HMO presence on pay. In column 2, we continue to include controls for state fixed effects but also control for the usual vector of hospital

${ }^{20}$ An opposing force towards a lowering of managerial pay could come from the wave of mergers and consolidations that have hit the hospital industry with managed care expansion. Such restructuring may have introduced more slack in the market for hospital top executives.

${ }^{21}$ In section 5, we will discuss another reason for an expected increase in mean pay. Pay seems to have become riskier because, as we will show, the link between pay and economic performance has become tighter. This would 
characteristics. We find that the effect of HMO penetration on mean pay, while still positive and significant, drops dramatically (0.6 instead of 1.7). This likely reflects a selective entry of HMOs in different geographical markets. For example, the pay of top executives is much lower among the hospitals that have a larger share of Medicaid patients. Hence, part of the large positive coefficient on HMO penetration in column 1 simply comes from the fact that HMOs are less likely to have a strong presence in markets where lower income people are more numerous. In column 3, we get around these important selection issues and look within hospitals. 22 There is no apparent sign of an increase in mean pay when we control for hospital fixed effects. In fact, the point estimate on HMO penetration in column 3 of Table 6 is now negative, though not statistically significant.

How can we explain this lack of a positive pay response? One explanation we already alluded to evolves around the lack of demographic controls for the managers. If newly appointed executives are younger and less experienced, they might on net be paid less than their predecessors. Column 4 in Table 6 indeed shows that, in the absence of CEO demographic controls, turnover is associated with a reduction in mean pay of about 5\%. This suggests an alternative approach. One could ask whether the turnover that happens in times of heightened HMO presence results in relatively smaller pay cuts. This would indicate that, assuming that the relative age and experience of new and old executives are stable at different levels of HMO penetration, the new executives that are appointed because of the changing hospital market are better paid, perhaps because of their superior business management skills. We study this idea in columns 5 and 6, where, in addition to the direct effect of HMO penetration, we add an interaction term between HMO penetration and a turnover indicator variable. Column 5 contains hospital characteristics and state fixed effects. We look within hospitals in column 6 . The interaction term is in both cases, as expected, positive, but not statistically significant.

require a standard adjustment up of mean pay in order to keep a risk-averse agent indifferent between the two contractual environments.

${ }^{22}$ This of course is assuming that the demographic characteristics of a given area are stable within the 5 -year window of our analysis. 
Note that another explanation for the lack of a strong positive pay effect could be that part of the effect of the HMO penetration was to reduce managerial rents in the not-for-profit sector. Such a view is at first glance inconsistent with the evidence already mentioned above from Roomkin and Weisbrod (1999) that indicates larger pay levels in the profit sector than in the not-for-profit sectors within specific managerial occupation and hospital size cells. However, their measure of pay might not capture a set of perks that might be easier to obtain in a not-for-profit environment. Moreover, various legislative efforts to cap the salaries of hospital executives and other hospital employees could be viewed as symptomatic of excess pay in that sector (see e.g. Nemes, 1992). In support of that alternative explanation, we found (in results not reported here) that the increase in turnover following HMO penetration was highest among the hospitals that paid the largest wage premium to their top executives.

\section{Has HMO Penetration Changed Pay-for-Performance?}

In section 3, we studied the basic relationship between the pay of top not-for-profit hospital executives and various for-profit and not-for-profit performance measures. In that section, we did not account for the role that HMO penetration may play in shaping or reshaping that relationship. Hence, while the importance of the for-profit objectives did not appear overwhelming in those earlier regressions (in fact, we found none among the more richly endowed hospitals), this might hide important changes over time. The turnover findings in the previous section already suggest that managed care pressures may have caused the removal of less financially oriented managers. More generally though, HMO penetration may have driven nonprofit boards to reconsider the objective function they want to maximize and what goals they want their executives, whether newly appointed or not, to fulfill. This section provides evidence on this.

In Table 7, we ask whether, as HMO penetration increases, the sensitivity of top executive compensation to economic measures of profitability increases as well. In columns 1 through 4, we use 
return on assets, defined as the ratio of hospital surplus (or deficit) over total assets, as the economic performance measure. Whether we control for state effects (column 1) or whether we allow for hospital fixed effects (column 2), we find that the sensitivity of pay to the rate of return on assets increases with HMO penetration. The magnitude of the effect is rather modest. For example, in column 2, a 1 percentage point increase in the rate of return on assets increases managerial pay by 0.4 percent more for each 10 extra percentage points in HMO market share.

Column 3 explores the possibility that the effect reported in columns 1 and 2 simply proxies for some overall increase in the link between pay and economic performance over time. Such a time trend could indeed very easily be reflected in a positive coefficient on the interaction term between HMO penetration and economic performance as the HMO penetration variable is trending up over time. We address this concern in column 3, where we again control for hospital effects but also allow for the coefficient on the return on assets measure to vary every year. The results are unaffected. In analyses not reported here, we have also verified that the results were robust to allowing the coefficients on economic performance to vary by state.

One additional concern one may have is that survivorship issues are biasing our results. Assume that there is heterogeneity across not-for-profit boards in how they reward their executives for good financial performance. Assume also that there is no change in the size of that pay-for-performance relationship with HMO penetration. Finally, assume that the hospitals that give high rewards for superior financial performance are more likely to survive in the more competitive environment. In that case, we could find that the link between pay and economic return goes up with HMO penetration while no single hospital board has in fact adjusted that link. We address this concern in column 4 . We replicate the specification of column 3 for a balanced panel, keeping only the hospitals for which we have data for all the years in the sample. The results are qualitatively unaffected. In fact, the point estimate on the interaction term between HMO penetration and return on assets is larger in column 4 than in column 3 (5.2 vs. 3.6). It thus does not appear that survivorship biases are driving our findings. 
In column 5, we ask whether the tightening of the link between pay and financial performance happens only through the appointment of new executives or whether incumbent managers also experience a change in their compensation package. We investigate that question by looking both "within" managers and hospitals instead of just looking "within" hospitals. In other words, we replicate the specification in column 3 but replace hospital fixed effects with hospital-manager fixed effects. The results are again unchanged. Hence, it appears that the stronger pay-for-financial performance relationship does not only occur through the hiring of new managers. Even incumbent managers on average experience a change in their compensation package when HMO penetration increases.

In columns 6 and 7, we replicate the analysis of column 3 but now respectively use total profitability margin and program services profitability margin as the for-profit performance measures. Again, we find a significant (even though statistically less so) increase in the sensitivity of managerial pay to these financial variables as HMO penetration increases.

Table 8 investigates whether HMO penetration also affected the financial reward of top hospital executives that provide better patient care and offer more charity care. In section 3, we saw that pay responded positively to increases in not-for-profit goals such as the per patient level of program service expenditures and the per patient number of full time doctors. We also showed, however, that a poorer proxy of care quality such as overall hospital expenditures (i.e. including non-program services expenditures and not relating the size of the expenditures to the pool of patients treated) had more explanatory power in a pay regression than arguably better proxies had. We now ask whether the nature and strength of these relationships between pay and these various expenditures and charity care measures was affected by the spread of HMOs. We control for hospital fixed effects in all regressions of Table 8.

In column 1 of Table 8, we consider the sensitivity of pay to program services expenditures per adjusted patient days. We find that the sensitivity of pay to the expenditure measure, in fact, increased with HMO penetration. Columns 2 and 3 show that more HMOs induced no clear increase, but no clear decrease either, in the reward of executives for providing larger medical staff per patient. In column 4 , 
we investigate whether the reward for providing charity care changed with HMO penetration. The coefficient on the interaction term between Medicaid market share and HMO market share is positive but not statistically significant.

In column 5, we replicate the specification of column 1 but allow for the HMO market share to simultaneously affect the link between total expenditures and pay and the link between per patient program services expenditures and pay. Interestingly, we find that HMO penetration increases the sensitivity of pay to the per patient program expenditure measure and decreases the sensitivity of pay to the total expenditure measure (this last effect is not precisely estimated though). One possible interpretation for this finding is that the new HMO-driven, financially constrained environment not only forced nonprofit boards to value more for-profit objectives but also led these boards to become more efficient in the pursuit of their not-for-profit objectives.

In summary, we find no direct decline in the reward for nonprofit objectives. In fact, column 6 confirms that the reward for more program spending per patient significantly increases with HMO penetration, even after accounting for the relationship between pay and return on assets found in Table 7. 23 One must however understand that managerial motivation to pursue the nonprofit objectives must be indirectly reduced through multi-tasking effects. The higher incentives to increase profits must indirectly hurt the quality of patient care (for example through lower nursing staffing) as well as the quantity of charity care provided.

\section{Impact on Public Donations}

The evidence presented so far in this paper strongly suggests that nonprofit hospitals have indeed become more profit-oriented in response to the growth in the managed care industry. As we mentioned in

\footnotetext{
${ }^{23}$ These higher pay-for-performance incentives may in part reflect the fact that HMO penetration has also made nonprofit boards more professional, independently of changing organizational goals. Once under financial
} 
the introduction, such a change in objectives is consistent with two different models of non-profit hospitals. Nonprofit hospitals could be truly altruistic but prefer to focus on economic goals when they face financial pressures and want to insure their long-run survival. Alternatively, nonprofit hospital boards may not be altruistic to start with and may have lost their ability to commit to soft for-profit incentives because of the drop in their revenues, as in Glaeser and Shleifer (1998). Whether the change in objectives was or was not consistent with the pure nonprofit mission could, in theory, be inferred from donors' behavior. Under the first model, one would not expect donors to "punish" the nonprofit hospitals if they understand that the new focus on economic profits is simply a way to guarantee the longevity of the organization and socially valuable intergenerational equity. Under the second model, on the other hand, one would expect donors to stop pouring resources into nonprofit hospitals if they no longer believe that the hospitals can commit to the soft incentives and high quality of services. We investigate this point in Table 9 where we study how public donations to nonprofit hospitals (expressed in fraction to total hospital revenue) reacted to the changes in HMO market shares. 24

All regressions in Table 9 include year effects, hospital effects and the usual vector of hospital characteristics. Whether we consider the sum of direct and indirect donations (column 1), direct donations alone (column 2), or indirect donations alone (column 3), the relationship to HMO market share is negative. Moreover, the relationship is statistically significant with respect to direct public donations and total donations. For example, in column 1, we find that a 1 percentage point increase in HMO market share decreases the fraction of revenues coming from public donations by 0.09 percentage point. Hence, consistent with the idea that donors no longer trust nonprofit hospitals to fulfill their nonprofit mission, public donations to non-profit hospitals decline as managed care expands.

pressures, more hospital boards may have realized that the structure of the compensation contract can be used as a tool to increase organizational success.

${ }^{24}$ The donation variables were extracted from the IRS data. Note that public donations represent a very small fraction of total revenues (less than one percent) for the hospitals in our sample. 


\section{Summary and Conclusion}

Do nonprofits change their mission in the face of increased market competition? This paper has provided indirect evidence on this question through a study of the managerial labor market in not-forprofit hospitals. Using a unique combination of data sources, we have found that the spread of managed care seems to have altered the objectives of nonprofit hospitals in interesting ways. We found that top executive turnover increases with HMO market share, especially among the hospitals that seem to be most stressed in terms of economic profitability and financial liability. Also, although the relationship between economic performance and top managerial pay in nonprofit hospitals is on average weak, we found that it strengthens with increases in HMO penetration. That is, nonprofit hospitals seem to behave more like for-profit firms in the face of a negative income shock. All these pieces of evidence are consistent with the idea that nonprofit hospitals experiencing negative shocks to their revenues appoint new managers that are better able to compete in the new market environment and reward old and new managers more for achieving for-profit goals. These results seem to be robust.

While our findings are in general consistent with the idea that HMOs have altered the mission of not-for-profit hospitals, they could also be framed in a less radical light. Indeed, an important part of the not-for-profit mission might be to insure that a high quality of care is provided not only to today's patients but also to future generations of patients. In other words, the long-run survival of the organization itself might be an important part of the not-for-profit goal. Achieving survival might then very naturally lead nonprofit boards to increase financial incentives when income-reducing shocks hit. However, the fact that donations also decrease with HMO market share suggests to us that this purely altruistic explanation of our results might not be the valid one.

A possible future extension of this work should focus on comparing the changes that we witness in the not-for-profit sector to the changes that may have occurred among for-profit hospitals. It would be especially interesting to study trends in top managerial pay in both organizational forms over time and as 
market conditions evolve. One also could learn a great deal from following top hospital managers as they move between organizational forms.

To what extent do policymakers want to continue giving tax breaks to nonprofit organizations if they are increasingly behaving like for-profit ones? This is a relevant and important policy question, especially in the context of the growing commercialization of many other not-for-profit sectors of the economy. Our paper strongly suggests that policymakers should indeed start questioning the social efficiency of promoting the development of not-for-profit organizations in sectors where strong market forces are at play. Future research should assess how generalizable our findings are to other not-for-profit sectors and other forms of income-reducing shocks. We hope that our work is a useful first step. 


\section{References}

Abelson, R. (1998). Nonprofit work gets profitable. New York Times, Sunday March 29.

Baker, L.C. (1995). County-level measures of HMO enrollment and market share. working paper, Stanford University.

Baker, L.C. \& Brown, M.L. (1997). The Effect of Managed Care on Health Care Providers. NBER working paper No. 5987.

Baker, L.C. \& Corts, C. (1996). HMO Penetration and the Cost of Healthcare: Market Discipline or Market Segmentation? American Economic Review Papers and Proceedings, 86(2), May, 389-94.

Baker, L.L. \& Skankarkumar, S. (1997). Managed Care and Health Care Expenditures: Evidence From Medicare, 1990-1994. NBER working paper No. 6187.

Brickley, J.A. \& Van Horn, R.L., (2000), Incentives in nonprofit organizations: Evidence from hospitals. working paper, University of Rochester.

Currie, J. \& Fahr, J., (2000). "Managed Care and Hospital Provision of Charity Care: The Case of California." working paper, University of California at Los Angeles.

Cutler, D. (Ed.), (2000). The changing hospital industry: Comparing not-for-profit and for-profit institutions. Chicago, IL: The University of Chicago Press.

Cutler, D., \& Horwitz, J.R. (2000). Converting hospitals from not-for-profit to for-profit status: Why and what effects. NBER working paper No. 6672.

Cutler, D., \& Seinfeld, J. (2000). Managerial Background and Decision Making: Evidence from the Hospital Industry. Working paper, Harvard University.

Drucker, (1999). Managing the Non-Profit Organization: Practices and Principles: New York, NY: Harper Collins.

Duggan, M. (2000). Hospital Market Structure and Medical Care for the Poor. working paper, University of Chicago.

Eldenberg, L., Hermalin, B.E., Weisbach, M.S., and Wosinka, M. (2000). Hospital Governance, Performance Objectives, and Organizational Form. working paper, University of Illinois.

Frank, R.G. \& Salkever, D.S. (2000). Market Forces, Diversification of Activity, and the Mission of Notfor-Profit Hospitals. In D.M. Cutler (Ed.), The Changing Hospital Industry: Comparing Not-forProfit and for-Profit Institutions, pp. 195-215. Chicago, IL: The University of Chicago Press.

Feldmann, S. \& Sharfstein, D. (2000). Managed Care and Provider Volume. In D.M. Cutler (Ed.), The Changing Hospital Industry: Comparing Not-for-Profit and for-Profit Institutions, pp. 229-248. Chicago, IL: The University of Chicago Press. 
Goddeeris, J.H., \& Weisbrod, B.A. (1998). Conversion from nonprofit to for-profit legal status: Why does it happen and should anyone care? In B.A. Weisbrod, (Ed.), To profit or not to profit: The commercial transformation of the nonprofit sector, pp. 129-148. Cambridge, MA: Cambridge University Press.

Gronbjerg, K.A. (1994). Using NTEE to classify nonprofit organizations: An assessment of human service and regional applications. Voluntas, 5(3), 301-28.

Glaeser, E.L., \& Shleifer, A. (1998). Not-for-profit entrepreneurs. NBER working paper No. 6810.

Hallock, K.F. (2000a). Managerial pay and governance in American nonprofits. working paper, University of Illinois at Urbana-Champaign.

Hallock, K.F. (2000b). Compensation in nonprofit organizations. Forthcoming in G.R. Ferris, (Ed.), Research in Personnel and Human Resources Management, JAI Press.

Hansmann, H.B. (1996). The organization of enterprise. Cambridge, MA: Harvard University Press.

Hodgkinson, V.A. (1990). Mapping the nonprofit sector in the United States: Implications for research. Voluntas, 12(2), 6-32.

Hodgkinson, V.A. \& Toppe, C.M. (1991). A new research and planning tool for managers: The national taxonomy of exempt entities. Nonprofit Management and Leadership, 1(4), 403-14.

Internal Revenue Service. (1996). Instructions to Form 990.

Jensen, M.C. \& Murphy, K.J. (1990). Performance pay and top management incentives. Journal of Political Economy, 98(2), 225-64.

Murphy, K.J., (1985). Corporate performance and managerial remuneration: An empirical analysis. Journal of Accounting and Economics, 7(1-3), 11-42.

Murphy, K.J., \& Zimmerman, J.L., (1993). Financial performance surrounding CEO turnover. Journal of Accounting and Economics, 16, 273-315.

Nemes, J. (1992). Hospital Executives' Pay Beginning to Raise Eyebrows. Modern Healthcare Weekly Business Review, June 8, 41-52.

Oster, S. (1998). Executive compensation in the nonprofit sector. Nonprofit Management and Leadership, 8(3), 1998, 207-21.

Pink, G.H., \& Leatt, P. (1991). Are managers compensated for hospital financial performance? Health Care Management Review, 16(3), 37-45.

Preston, A. (1989). The nonprofit worker in a for-profit world. Journal of Labor Economics, 7, 438-63.

Roomkin, M.J. \& Weisbrod, B.A. (1999). Managerial compensation in for-profit and nonprofit hospitals: Is these a difference? working paper, Northwestern University.

Rosen, S. (1992). Contracts and the market for executives. In L. Werin and H. Wijkander, (Eds.), Main Currents in Contract Economics. Oxford, UK: Blackwell. 
Stevenson, D., Pollak, T. \& Lampkin, L. (1997). The nonprofit almanac 1997: Profiles of charitable organizations. Washington DC: The Urban Institute Press.

Turner, S.E., Nygren, T.I. and Bowen, W.G. (1992). The NTEE classification system: Tests of reliability in the field of higher education. Voluntas, 4(1), 73.

Vancil, R. (1987). Passing the Baton: Managing the Process of CEO Succession. Boston, MA: Harvard Business School Press.

Warner, J.B., Watts, R.L., \& Wruck, K.H., (1988). Stock prices and top management changes. Journal of Financial Economics, 20, 461-92.

Weisbach, M. (1988). Outside directors and CEO turnover. Journal of Financial Economics, 20 (1-2), 431-60.

Weisbrod, B.A. (Ed.), (1998). To profit or not to profit: The commercial transformation of the nonprofit sector. Cambridge MA: Harvard University Press. 


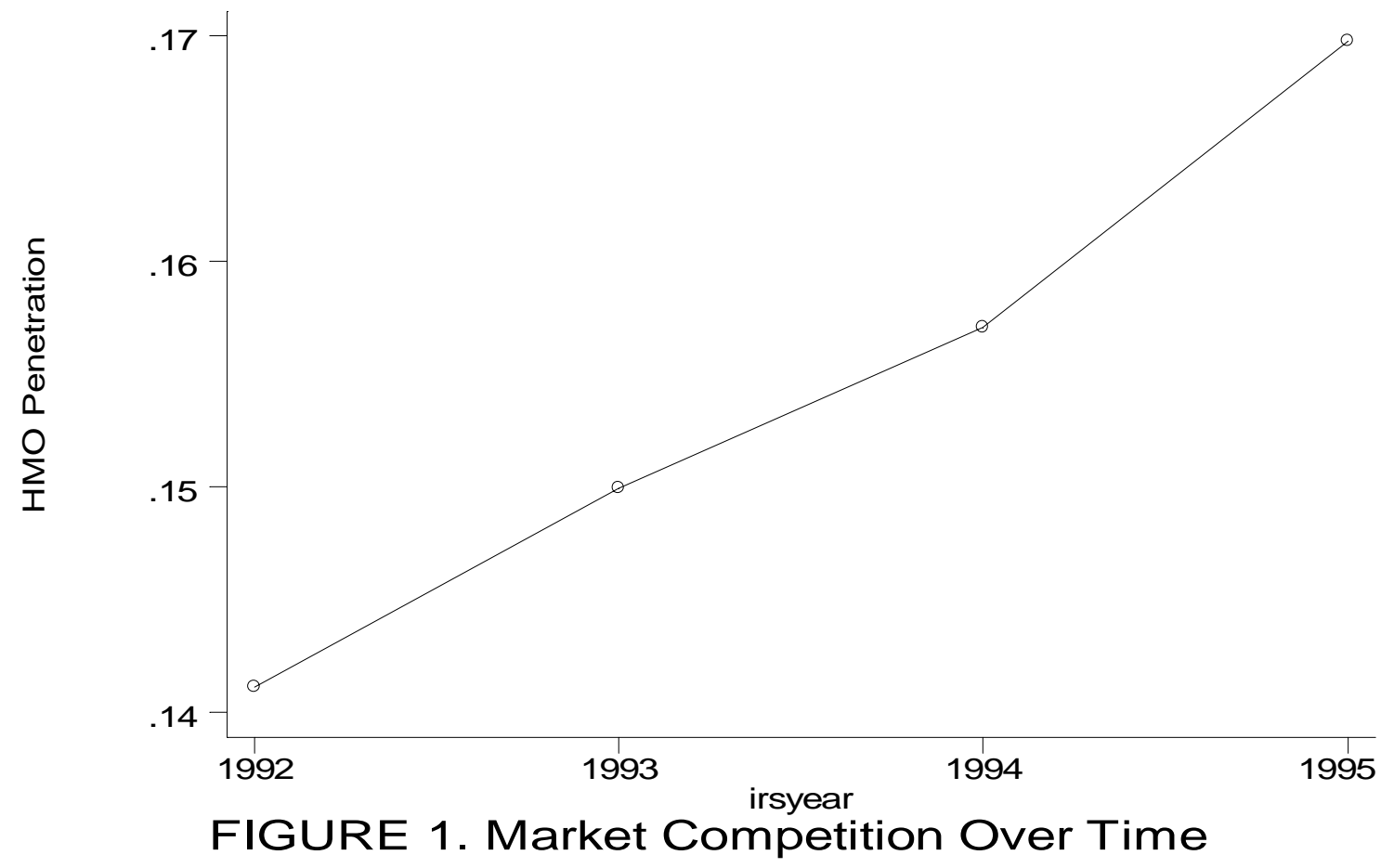


TABLE 1. Summary Statistics for Market Competition, Managers, and Hospitals ${ }^{(a)}$

\begin{tabular}{|c|c|}
\hline & All Hospita \\
\hline \multicolumn{2}{|l|}{ Market Competition } \\
\hline HMO Penetration Rate & $\begin{array}{c}0.154 \\
(0.002)\end{array}$ \\
\hline \multicolumn{2}{|l|}{ Hospital Managers (thousands) } \\
\hline Pay of Top Manager (levels) & $\begin{array}{c}240.958 \\
(8.451)\end{array}$ \\
\hline Pay of Top Manager (logs) & $\begin{array}{c}5.181 \\
(0.013)\end{array}$ \\
\hline Managerial Turnover (percent) & $\begin{array}{c}0.129 \\
(0.005)\end{array}$ \\
\hline \multicolumn{2}{|l|}{ Hospital Financials(thousands) } \\
\hline Assets & $\begin{array}{l}123016 \\
(3314)\end{array}$ \\
\hline Revenue & $\begin{array}{l}119158 \\
(2700)\end{array}$ \\
\hline Expenses & $\begin{array}{l}113375 \\
(2485)\end{array}$ \\
\hline Return $=(\operatorname{Rev}-\operatorname{Exp}) /$ Tot Assets & $\begin{array}{c}0.047 \\
(0.001)\end{array}$ \\
\hline Profit Margin $=(\operatorname{Rev}-\operatorname{Exp}) / \operatorname{Rev}$ & $\begin{array}{c}0.048 \\
(0.001)\end{array}$ \\
\hline Program Service (PS) Profit & 0.145 \\
\hline Margin & $(0.002)$ \\
\hline Leverage $=$ Liabilities $/$ Tot Assets & $\begin{array}{c}0.482 \\
(0.003)\end{array}$ \\
\hline
\end{tabular}

\begin{tabular}{lc} 
Nonprofit "Performance" & \\
Ln(Prog Exp/Patient Day) & -0.163 \\
& $(0.010)$ \\
Ln(Nurses/Patient Day) & -5.875 \\
& $(0.007)$ \\
Ln(Doctors/Patient Day) & -9.157 \\
$\mathrm{~N}$ & $(0.023)$ \\
\hline
\end{tabular}

Source: The data from IRS tax form 990 and the AHA Annual Survey for individual organizations for 1992-6. Notes: All data are reported in real 1996 thousands of dollars adjusted using the consumer price index. Standard errors are in parentheses. (a) Precise definitions of variables and data description are in the text. 
TABLE 2. The Determinants of Nonprofit Hospital Manager Pay: For-Profit Measures of Performance

\begin{tabular}{|c|c|c|c|c|c|c|c|c|c|c|}
\hline & (1) & (2) & (3) & (4) & (5) & (6) & (7) & (8) & (9) & (10) \\
\hline & & & & & & & & & $\begin{array}{c}\text { Base Year } \\
\text { Leverage }<0.5\end{array}$ & $\begin{array}{c}\text { Base Year } \\
\text { Leverage }>0.5\end{array}$ \\
\hline Return $=($ Rev-Exp $) /$ Assets & $\begin{array}{l}-0.078 \\
(0.243)\end{array}$ & $\begin{array}{l}-0.245 \\
(0.230)\end{array}$ & & & & & & & & \\
\hline Profit Margin & & & $\begin{array}{l}-0.471 \\
(0.230)\end{array}$ & $\begin{array}{l}-0.305 \\
(0.229)\end{array}$ & & & & & & \\
\hline Prog. Serv. Profit Margin & & & & & $\begin{array}{l}-0.108 \\
(0.100)\end{array}$ & $\begin{array}{l}-0.098 \\
(0.149)\end{array}$ & & & & \\
\hline Ln(Net Assets $)_{\mathrm{t}-1}$ & & & & & & & $\begin{array}{l}-0.052 \\
(0.026)\end{array}$ & $\begin{array}{c}0.080 \\
(0.041)\end{array}$ & $\begin{array}{c}0.010 \\
(0.067)\end{array}$ & $\begin{array}{c}0.123 \\
(0.051)\end{array}$ \\
\hline State fixed effects & Yes & No & Yes & No & Yes & No & Yes & No & No & No \\
\hline Hospital Fixed Effects & No & Yes & No & Yes & No & Yes & No & Yes & Yes & Yes \\
\hline $\mathrm{R}^{2}$ & 0.353 & 0.799 & 0.354 & 0.799 & 0.352 & 0.798 & 0.354 & 0.802 & 0.778 & 0.831 \\
\hline $\mathrm{N}$ & 4362 & 4362 & 4362 & 4362 & 4341 & 4341 & 2799 & 2799 & 1429 & 1370 \\
\hline
\end{tabular}

Source: The data from IRS tax form 990 and the AHA Annual Survey for individual organizations for 1992-6.

Notes: Dependent variable is $\ln$ (total compensation). OLS regressions. All specifications include controls for hospital characteristics which include: Medicare/adjusted patient day, $\ln$ (assets), total beds, $\ln$ (revenue), and indicator variables for whether the hospital has facilities for neonatal intensive care, trauma center, angioplasty, and open heart surgery.

All data are reported in real 1996 thousands of dollars adjusted using the consumer price index. All specifications include time indicator variables. Standard errors are in parentheses 
TABLE 3. The Determinants of Nonprofit Hospital Manager Turnover: For-Profit Measures of Performance

\begin{tabular}{|c|c|c|c|c|c|c|c|c|}
\hline & (1) & $(2)$ & $(3)$ & $(4)$ & $(5)$ & $(6)$ & $(7)$ & $(8)$ \\
\hline Return $=($ Rev-Exp $) /$ Assets $_{t-1}$ & $\begin{array}{c}-0.664 \\
(0.150)\end{array}$ & $\begin{array}{c}-0.839 \\
(0.271)\end{array}$ & & & & & & \\
\hline Profit Margin $_{t-1}$ & & & $\begin{array}{c}-0.694 \\
(0.141)\end{array}$ & $\begin{array}{l}-1.012 \\
(0.272)\end{array}$ & & & & \\
\hline Program Service Profit Margin $_{t-1}$ & & & & & $\begin{array}{l}-0.059 \\
(0.059)\end{array}$ & $\begin{array}{c}-0.504 \\
(0.190)\end{array}$ & & \\
\hline $\operatorname{Ln}(\text { Net Assets })_{t-1}$ & & & & & & & $\begin{array}{c}-0.007 \\
(0.012)\end{array}$ & $\begin{array}{c}-0.023 \\
(0.035)\end{array}$ \\
\hline State fixed effects & Yes & No & Yes & No & Yes & No & Yes & No \\
\hline Hospital Fixed Effects & No & Yes & No & Yes & No & Yes & No & Yes \\
\hline $\mathrm{R}^{2}$ & 0.019 & 0.054 & 0.021 & 0.057 & 0.014 & 0.054 & 0.012 & 0.048 \\
\hline $\mathrm{N}$ & 2784 & 2784 & 2784 & 2784 & 2772 & 2772 & 2784 & 2784 \\
\hline
\end{tabular}

Source: The data from IRS tax form 990 and the AHA Annual Survey for individual organizations for 1992-6.

Notes: Dependent variable equals one if new manager this year, and equals 0 otherwise. Linear probability model. All specifications include controls for hospital characteristics which include: Medicare/adjusted patient day, $\ln ($ assets), total beds, $\ln$ (revenue), and indicator variables for whether the hospital has facilities for neonatal intensive care, trauma center, angioplasty, and open heart surgery.

All data are reported in real 1996 thousands of dollars adjusted using the consumer price index. All specifications include time indicator variables.

Standard errors are in parentheses. 
TABLE 4. The Determinants of Nonprofit Hospital Manager Compensation: Nonprofit Measures of Performance

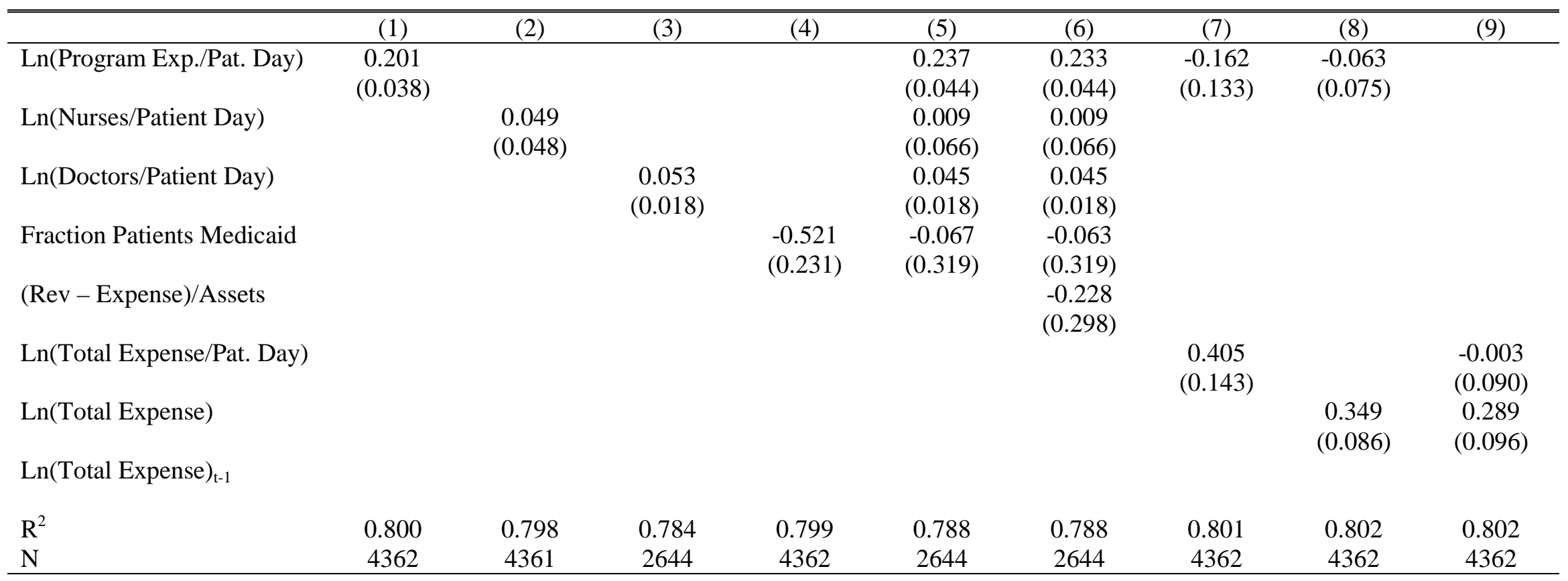

Source: The data from IRS tax form 990 and the AHA Annual Survey for individual organizations for 1992-6.

Notes: Dependent variable is $\ln ($ total compensation). OLS regressions. All specifications include hospital fixed effects. All specifications also include hospital characteristics which include: Medicare/adjusted patient day, Medicaid / adjusted patient day, $\ln ($ assets), total beds, $\ln ($ revenue), and indicator variables for whether the hospital has facilities for neonatal intensive care, trauma center, angioplasty, and open heart surgery.

All data are reported in real 1996 thousands of dollars adjusted using the consumer price index. All specifications include time indicator variables. Standard errors are in parentheses. 
TABLE 5. The Influence of Market Competition on Hospital Manager Turnover

\begin{tabular}{|c|c|c|c|c|c|c|c|c|c|c|c|c|}
\hline & $\overline{(1)}$ & (2) & (3) & (4) & $\overline{(5)}$ & $(6)$ & $(7)$ & $(8)$ & (9) & $(10)$ & $(11)$ & $(12)$ \\
\hline HMO Penetration & $\begin{array}{c}0.704 \\
(0.268)\end{array}$ & $\begin{array}{c}0.838 \\
(0.315)\end{array}$ & $\begin{array}{c}0.727 \\
(0.268)\end{array}$ & $\begin{array}{c}0.711 \\
(0.268)\end{array}$ & $\begin{array}{c}-1.632 \\
(2.445)\end{array}$ & $\begin{array}{c}-0.210 \\
(0.641)\end{array}$ & $\begin{array}{l}-1.758 \\
(2.450)\end{array}$ & $\begin{array}{c}0.706 \\
(0.281)\end{array}$ & $\begin{array}{c}1.331 \\
(3.040)\end{array}$ & $\begin{array}{l}-1.526 \\
(2.049)\end{array}$ & $\begin{array}{c}0.249 \\
(0.366)\end{array}$ & $\begin{array}{c}-0.384 \\
(0.659)\end{array}$ \\
\hline BaseYr Return*HMO & & $\begin{array}{c}-3.881 \\
(4.795)\end{array}$ & & & & & & & & & & \\
\hline BaseYr. Prof. Margin*HMO & & & $\begin{array}{c}-0.671 \\
(0.285)\end{array}$ & & $\begin{array}{c}-0.674 \\
(0.285)\end{array}$ & & & & & & & $\begin{array}{c}-0.663 \\
(0.285)\end{array}$ \\
\hline BaseYr PS Prof Margin*HMO & & & & $\begin{array}{c}-0.119 \\
(0.066)\end{array}$ & & & & & & & & \\
\hline BaseYr. Debt/Assets*HMO & & & & & & $\begin{array}{c}1.739 \\
(1.107)\end{array}$ & $\begin{array}{c}1.599 \\
(1.128)\end{array}$ & & & & & $\begin{array}{c}1.442 \\
(1.122)\end{array}$ \\
\hline BaseYr Prg. Exp/Pat. Day*HMO & & & & & & & & $\begin{array}{c}0.010 \\
(0.355)\end{array}$ & & & & \\
\hline Base Yr Nurses/Pat Day*HMO & & & & & & & & & $\begin{array}{c}0.106 \\
(0.511)\end{array}$ & & & \\
\hline Base Yr Doc/Pat Day*HMO & & & & & & & & & & $\begin{array}{c}-0.215 \\
(0.215)\end{array}$ & & \\
\hline BaseYr LnAssets*HMO & & & & & $\begin{array}{c}0.210 \\
(0.216)\end{array}$ & & $\begin{array}{c}0.144 \\
(0.220)\end{array}$ & & & & & \\
\hline Base Yr Medicaid Share * HMO & & & & & & & & & & & $\begin{array}{c}4.185 \\
(2.549)\end{array}$ & $\begin{array}{c}3.600 \\
(2.582)\end{array}$ \\
\hline $\mathrm{R}^{2}$ & 0.049 & 0.049 & 0.051 & 0.051 & 0.051 & 0.050 & 0.050 & 0.049 & 0.049 & 0.041 & 0.050 & 0.052 \\
\hline $\mathrm{N}$ & 4259 & 4259 & 4259 & 4250 & 4259 & 4259 & 4259 & 4259 & 4259 & 3147 & 4259 & 4259 \\
\hline
\end{tabular}

Source: The data from IRS tax form 990 and the AHA Annual Survey for individual organizations for 1992-6. HMO data are from Baker (1995).

Notes: Dependent variable equals one if new manager this year, and equals 0 otherwise. Linear probability model. All specifications control for hospital fixed effects. All specifications also control for hospital characteristics which include: Medicare/adjusted patient day, $\ln$ (assets), total beds, $\ln$ (revenue), and indicator variables for whether the hospital has facilities for neonatal intensive care, trauma center, angioplasty, and open heart surgery. All data are reported in real 1996 thousands of dollars adjusted using the consumer price index. All Specifications include time indicator variables. Standard errors are in parentheses. 
TABLE 6. The Effect of Market Competition Hospital Manager Pay

\begin{tabular}{|c|c|c|c|c|c|c|}
\hline & $(1)$ & $(2)$ & (3) & (4) & $(5)$ & (6) \\
\hline HMO Penetration & $\begin{array}{c}1.719 \\
(0.139)\end{array}$ & $\begin{array}{c}0.600 \\
(0.126)\end{array}$ & $\begin{array}{c}-0.143 \\
(0.331)\end{array}$ & & $\begin{array}{c}0.549 \\
(0.132)\end{array}$ & $\begin{array}{c}-0.154 \\
(0.335)\end{array}$ \\
\hline Managerial Turnover & & & & $\begin{array}{l}-0.047 \\
(0.023)\end{array}$ & $\begin{array}{l}-0.112 \\
(0.055)\end{array}$ & $\begin{array}{l}-0.080 \\
(0.039)\end{array}$ \\
\hline Man. Turnover * HMO Pen. & & & & & $\begin{array}{c}0.314 \\
(0.260)\end{array}$ & $\begin{array}{c}0.183 \\
(0.184)\end{array}$ \\
\hline Hospital Characteristics $^{(a)}$ & No & Yes & Yes & Yes & Yes & Yes \\
\hline State fixed effects & Yes & Yes & No & No & Yes & No \\
\hline Hospital Fixed Effects & No & No & Yes & Yes & No & Yes \\
\hline $\mathrm{R}^{2}$ & 0.134 & 0.354 & 0.799 & 0.799 & 0.354 & 0.800 \\
\hline $\mathrm{N}$ & 4306 & 4300 & 4300 & 4321 & 4259 & 4259 \\
\hline
\end{tabular}

Source: The data from IRS tax form 990 and the AHA Annual Survey for individual organizations for 1992-6. HMO data are from Baker (1995). Notes: Dependent variable is $\ln ($ total compensation). OLS regressions. (a) Hospital characteristics include: Medicare/adjusted patient day, $\ln$ (assets), total beds, $\ln$ (revenue), and indicator variables for whether the hospital has facilities for neonatal intensive care, trauma center, angioplasty, and open heart surgery.

All data are reported in real 1996 thousands of dollars adjusted using the consumer price index. All Specifications include time indicator variables. Standard errors are in parentheses. 
TABLE 7. The Influence of Market Competition on the Hospital Manager Pay-to-Economic Performance Link

\begin{tabular}{|c|c|c|c|c|c|c|c|}
\hline & (1) & (2) & (3) & $(4)^{(\mathrm{a})}$ & (5) & (6) & (7) \\
\hline \multirow[t]{2}{*}{ HMO Penetration } & 0.286 & -0.464 & -0.459 & -0.470 & -0.149 & -0.453 & -0.504 \\
\hline & $(0.139)$ & $(0.317)$ & $(0.320)$ & $(0.412)$ & $(0.337)$ & $(0.320)$ & $(0.342)$ \\
\hline \multirow[t]{2}{*}{ Return } & -1.101 & -0.826 & -0.505 & -0.995 & -0.267 & & \\
\hline & $(0.361)$ & $(0.332)$ & $(0.405)$ & $(0.559)$ & $(0.414)$ & & \\
\hline \multirow[t]{2}{*}{ Return*HMO Pen. } & 7.147 & 3.658 & 3.587 & 5.212 & 3.291 & & \\
\hline & (1.697) & $(1.600)$ & (1.624) & $(2.434)$ & $(1.700)$ & & \\
\hline \multirow[t]{2}{*}{ Profit Margin } & & & & & & -0.237 & \\
\hline & & & & & & $(0.393)$ & \\
\hline \multirow[t]{2}{*}{ Profit Margin*HMO Pen } & & & & & & 2.694 & \\
\hline & & & & & & $(1.529)$ & \\
\hline \multirow[t]{2}{*}{ Prog. Serv. P. Marg. } & & & & & & & -0.026 \\
\hline & & & & & & & $(0.227)$ \\
\hline \multirow{2}{*}{\multicolumn{2}{|c|}{ Prog. Serv. P. Marg *HMO }} & & & & & & 1.890 \\
\hline & & & & & & & $(1.013)$ \\
\hline State fixed effects & Yes & No & No & No & No & No & No \\
\hline Hospital Fixed Effects & No & Yes & Yes & Yes & No & Yes & Yes \\
\hline Hosp.Manager Fixed Effects & No & No & No & No & Yes & No & No \\
\hline Year*Performance Effects & No & No & Yes & Yes & Yes & Yes & Yes \\
\hline $\mathrm{R}^{2}$ & 0.367 & 0.811 & 0.811 & 0.788 & 0.837 & 0.811 & 0.810 \\
\hline $\mathrm{N}$ & 4300 & 4300 & 4300 & 2137 & 4286 & 4300 & 4279 \\
\hline
\end{tabular}

Source: The data from IRS tax form 990 and the AHA Annual Survey for individual organizations for 1992-6. HMO data are from Baker (1995). Notes: Dependent variable is $\ln$ (total compensation). OLS regressions. (a) Repeats specification from column (3) on a balanced sample. All specifications include controls for hospital characteristics including: Medicare/adjusted patient day, $\ln ($ assets), total beds, $\ln$ (revenue), and indicator variables for whether the hospital has facilities for neonatal intensive care, trauma center, angioplasty, and open heart surgery.

All data are reported in real 1996 thousands of dollars adjusted using the consumer price index. All Specifications include time indicator variables. Standard errors are in parentheses. 
TABLE 8. The Influence of Market Competition on the Hospital Manager Pay-to-Nonprofit-Performance Link

\begin{tabular}{|c|c|c|c|c|c|c|}
\hline & $\overline{(1)}$ & $\overline{(2)}$ & (3) & $\overline{(4)}$ & $\overline{(5)}$ & $\overline{(6)}$ \\
\hline HMO Penetration & $\begin{array}{l}-0.255 \\
(0.309)\end{array}$ & $\begin{array}{c}0.698 \\
(1.693)\end{array}$ & $\begin{array}{c}0.555 \\
(1.138)\end{array}$ & $\begin{array}{l}-0.452 \\
(0.339)\end{array}$ & $\begin{array}{c}2.328 \\
(3.280)\end{array}$ & $\begin{array}{c}-0.421 \\
(0.317)\end{array}$ \\
\hline Ln(Pr.Serv.Exp/Pat. Days) & $\begin{array}{c}0.095 \\
(0.057)\end{array}$ & & & & $\begin{array}{l}-0.163 \\
(0.088)\end{array}$ & $\begin{array}{c}0.095 \\
(0.058)\end{array}$ \\
\hline Ln(PS Exp/P.Days)*HMO Pen. & $\begin{array}{c}0.406 \\
(0.209)\end{array}$ & & & & $\begin{array}{c}0.476 \\
(0.310)\end{array}$ & $\begin{array}{c}0.397 \\
(0.209)\end{array}$ \\
\hline Ln(Nurses/Pat. Days) & & $\begin{array}{c}0.020 \\
(0.065)\end{array}$ & & & & \\
\hline Ln(Nurses/Pat. Days)*HMO Pen & & $\begin{array}{c}0.172 \\
(0.284)\end{array}$ & & & & \\
\hline Ln(Doctors/Pat. Days) & & & $\begin{array}{c}0.033 \\
(0.028)\end{array}$ & & & \\
\hline Ln(Docs/P. Days)*HMO Pen. & & & $\begin{array}{c}0.085 \\
(0.122)\end{array}$ & & & \\
\hline Medicaid Market Share & & & & $\begin{array}{l}-0.666 \\
(0.307)\end{array}$ & & \\
\hline Medicaid Mkt Share * HMO Pen. & & & & $\begin{array}{c}1.624 \\
(1.422)\end{array}$ & & \\
\hline Ln (Total Expense) & & & & & $\begin{array}{c}0.370 \\
(0.095)\end{array}$ & \\
\hline Ln (Total Expense)* HMO Pen. & & & & & $\begin{array}{l}-0.220 \\
(0.285)\end{array}$ & \\
\hline Return & & & & & & $\begin{array}{c}-0.716 \\
(0.331)\end{array}$ \\
\hline Return* HMO Penetration & & & & & & $\begin{array}{c}3.663 \\
(1.592)\end{array}$ \\
\hline $\mathrm{R}^{2}$ & 0.812 & 0.810 & 0.795 & 0.810 & 0.813 & 0.812 \\
\hline $\mathrm{N}$ & 4300 & 4299 & 2607 & 4300 & 4300 & 4300 \\
\hline
\end{tabular}
Notes: Dep. Var. is $\ln ($ total Compensation). OLS regressions. All specifications control for hospital fixed effects. All specifications control for hospital characteristics which include: Medicare/adjusted
patient day, $\ln ($ assets), total beds, $\ln ($ revenue), and indicator variables for whether the hospital has facilities for neonatal intensive care, trauma center, angioplasty, and open heart surgery. All data are reported in real 1996 thousands of dollars adjusted using the consumer price index. All Specifications include time indicator variables. Standard errors are in parentheses. 
TABLE 9. The Impact of HMO Penetration on the Rate of Donations

\begin{tabular}{|c|c|c|c|}
\hline & (1) & (2) & (3) \\
\hline & $\begin{array}{c}\text { Dependent Variable: } \\
(\text { Pub. Indirect }+ \text { Pub. Direct Support }) / \\
\text { Revenue }\end{array}$ & $\begin{array}{c}\text { Dependent Variable: } \\
\text { (Public Direct Support)/Revenue }\end{array}$ & $\begin{array}{c}\text { Dependent Variable: } \\
\text { (Public Indirect Support)/Revenue }\end{array}$ \\
\hline HMO Penetration & $\begin{array}{l}-0.087 \\
(0.023)\end{array}$ & $\begin{array}{l}-0.077 \\
(0.022)\end{array}$ & $\begin{array}{l}-0.010 \\
(0.006)\end{array}$ \\
\hline $\mathrm{R}^{2}$ & 0.585 & 0.596 & 0.392 \\
\hline
\end{tabular}

Source: The data from IRS tax form 990 and the AHA Annual Survey for individual organizations for 1992-6. HMO data are from Baker (1995). Notes: All specifications include hospital fixed effects. All specifications also control for hospital characteristics which include:

Medicare/adjusted patient day, $\ln$ (assets), total beds, $\ln$ (revenue), and indicator variables for whether the hospital has facilities for neonatal intensive care, trauma center, angioplasty, and open heart surgery.

All data are reported in real 1996 thousands of dollars adjusted using the consumer price index. All specifications include time indicator variables. Standard errors are in parentheses. 